\section{Evaluation of Cellular Proliferative Activity in Patients with Oral Lichen Planus and Hepatitis C through AgNoR Method}

João Paulo De Carli ${ }^{1}$, Soluete Oliveira da Silva ${ }^{2}$, Maria Salete Sandini Linden ${ }^{3}$, Carmen Silvia Busin ${ }^{4}$, Luiz Renato Paranhos ${ }^{5}$, Paulo Henrique Couto Souza ${ }^{6}$

\author{
'Department of Stomatology and Oral \\ Implant Dentistry, UPF - University of \\ Passo Fundo, Passo Fundo, RS, Brazil \\ 2Department of Stomatology, \\ UPF - University of Passo Fundo, \\ Passo Fundo, RS, Brazil \\ ${ }^{3}$ Department of Oral Implant, \\ UPF - University of Passo Fundo, \\ Passo Fundo, RS, Brazil \\ ${ }^{4}$ Department of Cellular Biology, \\ UPF - University of Passo Fundo, \\ Passo Fundo, RS, Brazil \\ ${ }^{5}$ Department of Dentistry, \\ UFS - Federal University of \\ Sergipe, Lagarto, SE, Brazil \\ ${ }^{6}$ Department of Stomatology, PUC- \\ PR - Pontifical Catholic University \\ of Paraná, Curitiba, PR, Brazil
}

\begin{abstract}
Correspondence: João Paulo De Carli, Correspondence: João Paulo De Carli, Universidade de Passo Fundo, Faculdade de Odontologia, BR 285, Km 171, Bairro São José, 99001-970 Passo Fundo, RS, Brasil. Tel.: +55-549112-3079. e-mail: joaodecarli@upf.br
\end{abstract}

Key Words: hepatitis $C_{\text {, }}$ lichen planus, cell nucleolus, cell proliferation.

\section{Introduction}

Lichen Planus is a mucocutaneous disease of uncertain etiology, which affects the oral mucosa. The relationship between Oral Lichen Planus (OLP) and the Hepatitis C Virus (HCV) infection has been widely studied. This relation suggests that HCV may be an etiological factor of OLP (1). Thus, the analysis of patients with OLP and HCV-infected would be useful to clarify the relation between these diseases.

The Nucleolar Organizer Regions (NORs) are structures present within the nucleolus of interphase cells and pairs of acrocentric chromosomes 13, 14, 15, 21 and 22 in human cells while dividing. A previous study (2) applied the AgNOR method on material of patients with OLP, oral keratosis and normal oral mucosa. As result, the authors report that the number of keratinocyte NORs was significantly higher in patients with OLP when compared to other groups. In a recent study, Selvi et al. (3) proved that the AgNOR method is applicable on epithelial cells of the mouth, by counting the number of NORs, in order to evaluate the age of a sample of individuals.

Despite several clinical studies demonstrating an association between HCV infection and the presence of OLP1, there are no studies to date linking the nucleolar condition of oral mucosa of patients with HCV and OLP.

Gandolfo et al. (4) evaluated 402 patients with OLP and found that patients infected with HCV had a three times higher chance of developing oral cancer compared to the non-infected. These results not only reinforce suspicions about the potential for malignant transformation of OLP, as they call attention to the participation of HCV in the canceration process.

Therefore, this study aimed to evaluate the cellular proliferative potential of OLP lesions from patients without $\mathrm{HCV}$ and the cellular proliferative potential of normal oral mucosa from patients with HCV, treated or untreated, by means of the AgNOR method.

\section{Material and Methods}

This study was approved by the Ethics Committee of the University of Passo Fundo, RS, Brazil, under protocol \#266/2011, assuring that the present research has followed ethical and legal principles.

A cross sectional observational histochemical study (AgNOR method) using the oral mucosa of four groups of patients was conducted as described below.

Groups 1 and 2 - Twenty HCV+ patients, confirmed by examining anti-HCV (Enzyme-Linked Immunosorbent Assay 
- ELISA) and HCV-RNA, treated at the Hospital São Vicente de Paulo of Passo Fundo, RS, Brazil, without clinical signs of OLP. In this group 10 patients had never been treated for $\mathrm{HCV}$ infection and 10 were under interferon and ribavirin treatment for a minimum period of three months;

Group 3 - Fifteen patients with reticular OLP, confirmed by histopathology, from the Dental School of the University of Passo Fundo, RS, Brazil. These patients did not have HCV infection, confirmed by anti-HCV exam;

Group 4 - Fifteen graduate students/professors from Dental School of the University of Passo Fundo, RS, Brazil, blood donors, without HCV infection, confirmed by antiHCV test, and without clinical signs of OLP (Control Group).

Inclusion criteria for the study were: 1 ) patients with hepatitis C proven by means of ELISA and HCV-RNA (for HCV+ Groups), 2) patients with OLP clinically and histopathologically confirmed (for OLP+ Group), and 3) patients without HCV infection or OLP (for Control Group).

Exclusion criteria were: 1) patients with hepatitis $C$ confirmed only by ELISA (for HCV+ Groups), 2) patients with metallic dental restorations or using drugs that could cause lichenoid lesions and 3) patients without hematological conditions (thrombocytes below $50,000 / \mathrm{mm}^{3}$ blood) (for $\vec{D}$ OLP+ Group), 4) patients with HCV infection or OLP (for Control Group).

To perform the clinical and histopathological analyses of OLP lesions, the criteria proposed by Krutchkoff et al. (5) and van der Meij and van der Waal (6) were used.

The mucosal samples to submit to the AgNOR method were collected by the liquid-based cytology technique. For this, all patients were initially instructed to perform a mouth rinse with water to remove any food debris.

The collection of cells was performed with a DNACitoliq" (Digene Corporation, Gaithersburg, MD, USA) kit system containing a liquid called Universal Collection Medium (UCM). This kit includes a vial containing $1 \mathrm{~mL}$ UCM and a brush with a long handle.

Oral mucosa cells were collected applying the brush in gently rotating clockwise movements (five laps). Then, the brush was dipped in the bottle containing UCM, remaining immersed in the liquid until the final processing. After collection, the bottle was shaken for $30 \mathrm{~s}$ to homogenize the material, which remained at room temperature (dry, fresh and protected from light) for a period no longer than three weeks, according to manufacturer's recommendations.

The processing of material consisted of his triple spin $(1,000$ r.p.m.); the first only with UCM and the second and third ones with the sediment material mixed with a fixative solution of acetic acid/methanol (3:1). Then, the sediment material from each patient was dripped on a microscope slide and filled with the AgNOR method.

The use of AgNOR technique was carried out according to Ploton et al. (7) with some modifications, as reported:

1) Obtaining the sediment material by centrifugation and dripping it on a microscope slide;

2) Preparation of silver solutions for AgNOR, as follows:

- solution A: $50 \mathrm{~mL}$ Milli-0 water, $0.5 \mathrm{~mL}$ formic acid and $1 \mathrm{~g}$ gelatin; this solution was kept in an incubator at $45^{\circ} \mathrm{C}$ for $1 \mathrm{~h}$ before incubation;

- solution B: $10 \mathrm{~mL}$ distilled water and $5 \mathrm{~g}$ silver nitrate.

3) The solutions A and B were mixed and dripped onto the cell material on the blade, staying for $30 \mathrm{~min}$ in an oven at $45^{\circ} \mathrm{C}$ and then dried.

Count of NORs was performed on 100 epithelial cell nuclei per lesion. Two blind observers analyzed independently the silver-stained cells on microphotographs obtained with a digital camera (Canon'"' Power Short A620, Canon do Brasil, São Paulo, SP, Brazil) connected to a light microscope (Olympus' $\mathrm{BX}$ 50; Olympus Corporation of the Americas, Center Valley, PA, USA) with immersion objective $(1000 \times)$. To obtain the microphotographs, all the slides refereeing to each patient were analyzed horizontally from left to right and the nuclei of the first 100 non-overlapping, well-fixed nucleated cells were recorded. The count of NORs was performed using the Image Tool ${ }^{\mathrm{m}}$ version 3.0 (Department of Dental Diagnostic Science at The University of Texas Health Science Center, San Antonio, TX, USA), in which the nucleus of each cell was "cut" by the "save selection as" tool and enlarged for better viewing (Fig. 1). Data for each case were related between the groups by Tukey HSD test (significance level of 95\% - $p<0.05$ ). Inter and intra-observer agreements were done by Dahlberg error.

\section{Results}

The NORs of 50 patients were recorded (100 nuclei from each patient), and their epidemiological characteristics are described in Table 1.

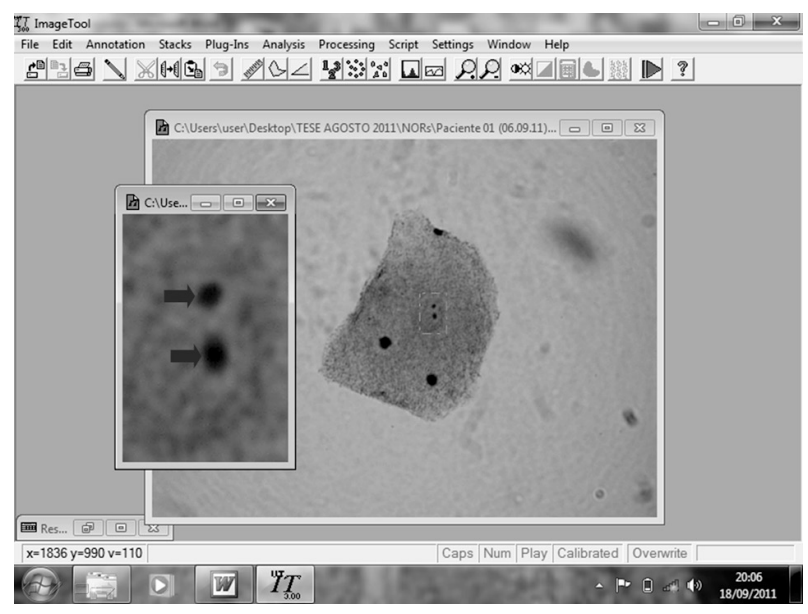

Figure 1. Nucleus image "cut" and enlarged for counting of NORs (arrows) (AgNOR, 1000x, personal file). 
Regarding the inter and intra-examiners evaluations, it was observed that Dahlberg's error did not exceed $0.03 \%$ for both comparisons, indicating that the evaluators repeated the measurement with high reliability for the variable NORs in 100 nuclei (Table 2).

Normality tests of Kolmogorov-Smirnov and ShapiroWilk were applied to the average number of NORs of 100 nuclei for the 50 patients and indicated normal distribution of data, since $p$ values were higher than 0.05 . Furthermore, Levene's test showed homogeneity of variance among groups (Levene's test value $=1.3739 ; p=0.2626$ ).

When applying tests of "between-subjects effects" (ANOVA) to mean NORs in 100 cell nuclei obtained from each patient, a $p$-value $=0.00084(\mathrm{~F}=6.603)$ was observed, which indicated that the variable NORs show some difference in index values between the groups (test power of $96.08 \%$ ). Then, the Tukey HSD multiple comparisons test was applied and showed that the mean of NORs in the group of previously treated $\mathrm{HCV}_{+}$ patients was significantly higher than in other groups. Figure 2 shows the means of NORs in 100 nuclei of each case of the studied groups, the confidence intervals of such groups and their statistical differences verified by Tukey HSD test.

\section{Discussion}

Considering the studied groups in this work, it was possible to infer that previously treated $\mathrm{HCV}_{+}$patients had a higher average number of NORs in relation to others, indicating a higher proliferative activity of tissue, probably due to the effect of anti-HCV treatment which may, according to previous clinical studies $(8,9)$, cause oral manifestations. However, in the current study it was not possible to determine when the HCV infection has initiated, since hepatitis C is often a silent disease, delaying its diagnosis. Furthermore, it was not possible to standardize the patients as regards the duration of performed anti-HCV treatment. Thus, it should be noted that both the time of HCV diagnosis and the duration of anti-HCV treatment are factors that may influence the result of the number of NORs.

The present results suggest that the higher cellular proliferative activity in previously treated $\mathrm{HCV}+$ patients may indicate a possible relationship between the latter condition and one of the histopathological manifestations of OLP, the cell proliferative activity. In this sense, Schlesinger et al. (10) described a case of OLP that started in a patient treated with interferon alfa-2b and Griffiths et al. (8) stated that interferon can induce the expression of surface antigens on keratinocytes, which may play an important role in the origin of lichen planus. Still, for Sookoian et al. (9), ribavirin increases the risk of adverse skin reactions, among them the $\operatorname{OLP}(11,12)$.
Figure 2. Confidence intervals, means and statistical differences of the studied groups relative to mean of NORs in 100 nuclei at level of 95\% (different letters indicate statistically significant difference). 
Li et al. (13) investigated the incidence and spectrum of dermatological adverse events during treatment of chronic hepatitis $C$ in 152 patients between January 2008 and December 2012. Among other lesions, the authors noted the presence of $14(9.2 \%)$ patients with eczematous reactions, two (1.3\%) patients with lichenoid eruption and one case of OLP and concluded that dermatological events resulting from interferon-alpha/ribavirin treatment of HCV contribute to a wide spectrum involving the skin, mucous membrane, hair and nails. The study of Li et al. (13) is in accordance with the present investigation, since the treatment for HCV has shown to result in adverse events among the studied patients.

Strumia et al. (14) reported that interferon may induce the migration of $T$ cells to the skin due to their ability to stimulate keratinocytes to produce interleukin-2. Complementing this information, Mourad et al. (15) affirmed that tumors of positive bone marrow interleukin-2 presented a significantly greater mean of NORs than healthy individuals, and Simark-Mattsson et al. (16) stated that the OLP cells of all cases studied by them expressed mRNA for interleukin-2. The previously described cellular events, plus the histochemical results of this study suggest that $\vec{s}$ interferon and/or ribavirin may increase the number of NORs per nucleus in oral mucosa cells, suggesting a possible relationship between anti-HCV treatment and OLP, clinical manifestation previously reported $(8,9,12)$.

However, this increase in cell proliferative activity of previously treated $\mathrm{HCV}+$ patients may also be associated with other oral diseases, such as oral dysplasia or carcinoma. Basing this statement clinically, Gandolfo et al. (4) evaluated patients with OLP and followed them up periodically. These authors reported that patients infected with HCV had a three times greater chance of developing oral cancer than those not infected. Despite these results, Gandolfo et al. (4) did not mention whether or not the patients were under antiviral treatment for $\mathrm{HCV}$, unlike the present study. These findings draw attention to the involvement of $\mathrm{HCV}$ in tissue increased cell proliferation.

It was also noted that the oral verrucous carcinoma and the squamous cell carcinoma have been described in patients infected with $\mathrm{HCV}$, regardless of the presence of OLP $(17,18)$. Samples positive for HCV-RNA were detected in tissues of oral cancer (19) and OLP (20). Some of HCV proteins, called "the core" and "the non-structural 3 protein", can accelerate the cell cycle in vitro $(21,22)$. Such statement may explain why previously treated HCV+ patients had a higher cell proliferative activity when compared to other groups.

Michele et al. (23) evaluated 165 patients affected by chronic HCV infection and followed up by three years. Considering the type of antiviral therapy used to cure the chronic hepatitis, 36 of the patients were "virgins" of treatment, and the remaining 129 were under treatment or had already finished treatment without clearance of the virus. The only two patients that presented lesions of OLP were under treatment with interferon and ribavirin during the exam. The authors affirmed that the possible risk factors associated with the presence of OLP indicated that only $\mathrm{HCV}$ chronic infection was statistically significant $(\mathrm{p}<0.05)$. Based on the results of the clinical study of Michele et al. (23) and on the histochemical results of the present study, it may be suggested that there is a possible link between anti-HCV treatment and OLP.

By means of a meta-analyses review, Carrozzo and Scally (24) affirmed that convincing epidemiological evidence supports the association between OLP and HCV. As HCV may replicate in the oral mucosa and attract virus-specific T lymphocytes, it may be implicated in OLP pathogenesis. In this study, the average number of NORs in the group of patients with OLP (3.30) was statistically equivalent to that of control patients (3.12) and HCV + patients with no previous treatment (3.19), and below the group of previously treated HCV+ patients (4.08).

The present results are different from those obtained by Silva Fonseca and Carmo (2), who affirmed that the average number of NORs was statistically higher in cases of OLP than in patients with normal oral mucosa. However, these authors conducted the silver impregnation on tissue preserved in formaldehyde, stored in paraffin and not on material from cytology as in the present study, which may have influenced the difference in results.

Cheng et al. (25), in a hospital survey, accessed extrahepatic manifestations in chronic HCV infection of 297 Chinese patients, of which only 33 had received prior treatment for the virus. Relative to extrahepatic manifestations of HCV, the authors noted rare cases of OLP in patients previously treated for HCV. Thus, the study of Cheng et al. (25) agrees with the present findings, since few cases of OLP were found in a sample of HCV+ patients.

The anti-HCV treatment may play a role on oral cell proliferative activity, justifying further longitudinal studies to confirm a possible higher prevalence of OLP in $\mathrm{HCV}+$ patients under treatment. However, other oral diseases, neoplastic for example, may also be related to the increased cell proliferation observed in the present study in $\mathrm{HCV}+$ patients under antiviral treatment, which must be carefully researched before the possible relationship between OLP and HCV.

\section{Resumo}

0 propósito deste estudo foi avaliar o potencial proliferativo celular das lesões de líquen plano bucal (LPB) de pacientes sem vírus da hepatite C $(\mathrm{VHC})$ por meio do método AgNOR, comparando-o ao potencial 
proliferativo celular da mucosa bucal normal de portadores de VHC, tratados ou não com interferon e ribavirina. Um estudo transversal foi realizado para investigar 4 grupos: 10 pacientes $\mathrm{VHC}+$ sem sinais clinicos de LPB que nunca haviam sido tratados para a infecção por VHC - Grupo 1; 10 pacientes $\mathrm{VHC}+$ que estavam sob tratamento com interferon e ribavirina - Grupo 2; 15 pacientes com LPB reticular histopatologicamente confirmado, sem VHC - Grupo 3; e 15 doadores de sangue sem infecção por VHC e sem sinais clínicos de LPB (Grupo 4 - Grupo de Controle). 0 material celular de todos os grupos foi coletado pela técnica da citologia em base liquida. Então, o material sedimentado de cada paciente foi submetido ao método da impregnação das regiões organizadoras nucleolares pela prata (AgNOR). A contagem das NORs foi realizada em 100 núcleos celulares epiteliais por paciente por meio do programa Image Tool ${ }^{\circledR}$. 0 teste Tukey HSD foi utilizado para comparar o valor médio de NORs entre os grupos e mostrou que a mucosa bucal dos pacientes $\mathrm{VHC}+$ previamente tratados com fármacos anti-VHC (Grupo 2) apresentou maior número médio de NORs por núcleo em relação aos outros $(p<0,05)$. 0 tratamento anti-VHC pode estar relacionado ao aumento da atividade proliferativa celular da mucosa bucal, aventando uma possivel relação entre LPB e pacientes $\mathrm{VHC}+$ tratados com interferon e ribavirina.

\section{References}

1. Vachiramon $V$, Suchonwanit $P$, Thadanipon $K$. Bilateral linear lichen planus pigmentosus associated with hepatitis $C$ virus infection. Case Rep Dermatol 2010;2:169-172.

2. Silva Fonseca LM, Carmo MAV. Identification of the AgNORs, PCNA and ck16 proteins in oral lichen planus lesions. Oral Diseases 2001;7:344348.

3. Selvi B, Demirtas H, Eroz R, Imamoglu N. Reduction of the argyrophilic nucleolar organizing region associated protein synthesis with age in buccal epithelial cells of healthy individuals. Aging Clin Exp Res 2014 [Epub ahead of print. DOI: 10.1007/s40520-014-0263-6].

4. Gandolfo $S$, Richiardi L, Carrozzo M, Brocolletti R, Carbone M, Pagano $M$, et al.. Risk of oral squamous cell carcinoma in 402 patients with oral lichen planus: a follow-up study in an Italian population. Oral Oncology 2004;40:77-83.

5. Krutchkoff D, Cutler L, Laskowski S. Oral lichen planus: the evidence regarding potential malignant transformation. J Oral Pathol Med 1978;7:1-7.

6. van der Meij EH, van der Waal I. Lack of clinicopathological correlation in the diagnosis of oral lichen planus based on the presently available criteria and suggestion for modification. J Oral Pathol Med 2003;32:507-512.

7. Ploton $D$, Menager $M$, Jeannesson $P$, Himber G, Pigeon $F$, Adnet JJ. Improvement in the staining and in the visualization of the argyrophilic proteins of the nucleolar organizer region of the optical level. Histochem J 1986;8:5-14.

8. Griffiths CE, Voorhees JJ, Nickoloff BJ. Characterization of intracelular adhesion molecule-I and HLA-DR expression in normal and inflamed skin: modulation by recombinant gamma interferon and tumor necrosis factor. J Am Acad Dermatol 1989;20:617-629.

9. Sookoian S, Neglia V, Castano V, Frider B, Kien MC, Chohela E. High prevalence of cutaneous reactions to interferon alfa plus ribavirin combination therapy in patients with chronic hepatitis $C$ virus. Arch Dermatol 1999;135:1000-1001.
10. Schlesinger TE, Camisa C, Gay JD, Bergfeld WF. Oral erosive lichen planus with epidermolytic hyperkeratosis during interferon alfa-2b therapy for chronic hepatitis C virus infection. J Am Acad Dermatol 1997;36:1023-1025.

11. Manjon-Haces JA, Vazquez-Lopez F, Gomez-Diez S, Hidalgo-García A, Pérez-Alvarez R, Soler-Sánchez T et al.. Adverse cutaneous reactions to interferon Alfa-2b plus ribavirin therapy in patients with chronic hepatitis C virus (letter). Acta Derm Venereol 2001;81:223.

12. Nagao $Y$, Kawaguchi T, Ide $T$, Kumashiro R, Sata M. Exacerbation of oral erosive lichen planus by combination of interferon and ribavirin therapy for chronic hepatitis C. Int J Mol Med 2005;15:237-241.

13. Li Z, Zhang $Y$, An J, Feng $Y$, Deng $H$, Xiao $S$, et al.. Predictive factors for adverse dermatological events during pegylated/interferon alpha and ribavirin treatment for hepatitis C. J Clin Virol 2014;60:190-195.

14. Strumia R, Venturini D, Boccia S, Gamberini S, Gullini S. UVA and interferon-alfa therapy in a patient with lichen planus and chronic hepatitis C [letter]. J Dermatol 1993;32:386.

15. Mourad WA, Pugh WC, Huh YO, Keating MJ. Cell kinetic analysis of interleukin-2 receptor-tested chronic lymphocytic leukemia using the AgNOR silver stain. Am J Clin Pathol 1994;101:300-304.

16. Simark-Mattsson C, Bergenholtz $G$, Jontell M, Eklund C, Seymour GJ, Sugerman PB. Distribution of interleukin-2, $-4,-10$, tumour necrosis factor-alpha and transforming growth factor-beta mRNAs in oral lichen planus. Arch Oral Biol 1999;44:499-507.

17. Carrozzo M, Gandolfo $S$, Carbone $M$, Colombatto $P$, Olivieri F. An atipical verrucous carcinoma of the tongue arising in a patient with oral lichen planus and hepatitis $C$ virus infection. Oral Oncol 1997;33:220-225.

18. Nagao $Y$, Sata M, Tanikawa $K$, Itoh $K$, Kameyama T. Lichen planus and hepatitis $C$ virus in the northern Kyushu region of Japan. Eur J Clin Invest 1995;25:910-914.

19. Nagao Y, Sata M, Noguchi S, Seno'o T, Kinoshita M, Kameyama T, et al.. Detection of hepatitis $C$ virus RNA in oral lichen planus and oral cancer tissues. J Oral Pathol Med 2000;29:259-266.

20. Arrieta JJ, Rodriguez-Iñigo E, Casqueiro M, Bartolomé J, Manzarbeitia $\mathrm{F}$, Herrero $\mathrm{M}$, et al.. Detection of hepatitis $\mathrm{C}$ virus replication by in situ hybridization in epithelial cells of anti-hepatitis $C$ virus-positive patients with and without oral lichen planus. Hepatology 2000;32:97103.

21. Ray RB, Lagging LM, Meyer K, Ray R. Hepatitis C virus core protein cooperates with ras and transforms primary rat embryo fibroblasts to tumorigenic phenotype. J Virol 1996;70:4438-4443.

22. Sakamuro D, Furukawa T, Takegami T. Hepatitis $C$ virus nonstructural protein NS3 transforms NIH 3T3 cells. J Virol 1995;69:3893-3896.

23. Michele G, Carlo L, Mario MC, Giovanni L, Pasquale M, Alessandra M. Hepatitis $C$ virus chronic infection and oral lichen planus: an Italian case-control study. Eur J Gastroenterol Hepatol 2007;19:647-652.

24. Carrozzo M, Scally K. Oral manifestations of hepatitis $C$ virus infection. World J Gastroenterol 2014;28;20:7534-7543.

25. Cheng Z, Zhou B, Shi X, Zhang Y, Zhang L, Chen L, et al.. Extrahepatic manifestations of chronic hepatitis $C$ virus infection: 297 cases from a tertiary medical center in Beijing, China. Chin Med J 2014;127:12061210. 